\title{
Glycogen Synthase and Phosphofructokinase Protein and mRNA Levels in Skeletal Muscle from Insulin-resistant Patients with Non-Insulin-dependent Diabetes Mellitus
}

\author{
Henrik Vestergaard, * Sten Lund, ${ }^{*}$ Flemming S. Larsen, ${ }^{5}$ Ole J. Bjerrum, ${ }^{\mathbf{3}}$ and Oluf Pedersen * \\ * Steno Diabetes Center, Copenhagen, Denmark; ${ }^{\ddagger}$ Division of Endocrinology and Metabolism, University Clinic of Internal Medicine C, \\ Aarhus Amtssygehus, Aarhus, Denmark; and ${ }^{\S}$ Novo Nordisk, Bagsvaerd, Denmark
}

\begin{abstract}
In patients with non-insulin-dependent diabetes mellitus (NIDDM) and matched control subjects we examined the interrelationships between in vivo nonoxidative glucose metabolism and glucose oxidation and the muscle activities, as well as the immunoreactive protein and mRNA levels of the rate-limiting enzymes in glycogen synthesis and glycolysis, glycogen synthase (GS) and phosphofructokinase (PFK), respectively. Analysis of biopsies of quadriceps muscle from 19 NIDDM patients and 19 control subjects showed in the basal state a $30 \%$ decrease $(P<0.005)$ in total GS activity and a $38 \%$ decrease $(P$ $<0.001$ ) in GS mRNA / $\mu$ g DNA in NIDDM patients, whereas the GS protein level was normal. The enzymatic activity and protein and mRNA levels of PFK were all normal in diabetic patients. In subgroups of NIDDM patients and control subjects an insulin-glucose clamp in combination with indirect calorimetry was performed. The rate of insulin-stimulated nonoxidative glucose metabolism was decreased by $47 \%(P<0.005)$ in NIDDM patients, whereas the glucose oxidation rate was normal. The PFK activity, protein level, and mRNA/ $\mu$ g DNA remained unchanged. The relative activation of GS by glucose-6-phosphate was $33 \%$ lower $(P<0.02)$, whereas GS mRNA $/ \mu$ gNA was $37 \%$ lower $(P<0.05)$ in the diabetic patients after $4 \mathrm{~h}$ of hyperinsulinemia. Total GS immunoreactive mass remained normal. In conclusion, qualitative but not quantitative posttranslational abnormalities of the GS protein in muscle determine the reduced insulin-stimulated nonoxidative glucose metabolism in NIDDM. (J. Clin. Invest. 1993. 91:2342-2350.) Key words: NIDDM • skeletal muscle • glycogen synthase protein $\bullet$ phosphofructokinase protein $\bullet$ mRNA
\end{abstract}

\section{Introduction}

When whole body glucose clearance is measured in man using the euglycemic, hyperinsulinemic clamp method, $\sim 75 \%$ of glucose is cleared by skeletal muscle tissue (see reference 1 for review). Once glucose has been taken up by skeletal muscle, it is irreversibly phosphorylated by hexokinase II to glucose-6-phosphate (G6P) ${ }^{1}$ and routed into either glucose

Address correspondence to Dr. Henrik Vestergaard, Steno Diabetes Center, Niels Steensensvej 2, DK-2820 Gentofte, Denmark.

Received for publication 16 June 1992 and in revised form 14 December 1992.

1. Abbreviations used in this paper: $\mathrm{F} 1,6 \mathrm{P}_{2}$, fructose-1,6-diphosphate; $\mathrm{F} 2,6 \mathrm{P}_{2}$, fructose-2,6-diphosphate; F6P, fructose-6-phosphate; G6P,

J. Clin. Invest.

(C) The American Society for Clinical Investigation, Inc.

$0021-9738 / 93 / 06 / 2342 / 09 \$ 2.00$

Volume 91, June 1993, 2342-2350 storage as glycogen or glycolysis. In turn, glycolysis leads to either lactate formation $(\sim 10 \%)$ or pyruvate oxidation in the Krebs cycle ( $\sim 90 \%$; reference 1$)$. In the low range of physiological hyperinsulinemia, glycogen synthesis and glycolysis are of equal quantitative importance (2). However, with increasing plasma insulin levels glycogen synthesis becomes the predominant pathway of glucose disposal $(2,3)$. Glycogen synthase (GS), which is a key enzyme in the muscle glycogen synthesis pathway, exists in an active dephosphorylated form and a less active phosphorylated form $(4,5)$. The two forms of the enzyme are interconverted by protein kinase and phosphatase reactions (4-6) with G6P allosterically activating the phosphorylated form of GS, whereas insulin acts covalently on GS by reducing and increasing the activities of specific kinases and phosphatase, respectively $(7,8)$. Phosphofructokinase (PFK) is a key step in muscle glycolysis (9), catalyzing the transformation of fructose-6-phosphate (F6P) to fructose-1,6-diphosphate $\left(\mathrm{F} 1,6 \mathrm{P}_{2}\right)$, a process that is allosterically regulated by several metabolites (9).

Under clamp conditions of euglycemia and hyperinsulinemia, glucose clearance in patients with non-insulin-dependent diabetes mellitus (NIDDM) is characteristically decreased by $30-50 \%$, with glucose storage being the quantitatively most affected pathway (1). Muscle glucose transport and GS are both insulin stimulated and each has separately been suggested to be responsible for the reduced rate of insulin-stimulated glucose disposal in NIDDM patients. Thus, impaired insulin-stimulated 3-O-methylglucose transport in muscle strips isolated from NIDDM patients has been reported (10, 11). Furthermore, studies in healthy volunteers and insulindependent diabetic subjects show that glucose transport is rate limiting for overall glucose disposal over a wide range of plasma insulin and glucose levels $(12,13)$. In patients with NIDDM, measurement of the muscle content of G6P by ${ }^{31} \mathrm{P}$ nuclear magnetic resonance during a hyperglycemic-hyperinsulinemic clamp showed a decrease in both G6P and nonoxidative glucose metabolism when compared with healthy controls. These findings are consistent with a defect in glucose transport or phosphorylation reducing the rate of muscle glycogen synthesis (14).

However, the latter suggestion is challenged by the results from two other groups of investigators $(15,16)$. When NIDDM patients and matched control subjects were examined with muscle biopsy sampling during similar glucose utilization rates and circulating insulin levels, diabetic patients had an increased intracellular concentration of free glucose and G6P

glucose-6-phosphate; GS, glycogen synthase; HGO, hepatic glucose output; NEFA, nonesterified fatty acids; NIDDM, non-insulin-dependent diabetes mellitus; PFK, phosphofructokinase; $\boldsymbol{R}_{\mathrm{d}}$, total glucose disposal rate. 
in muscle tissue, indicating that the rate-limiting step in muscle glucose metabolism in patients with NIDDM is located after G6P. Moreover, several abnormalities in the activation of GS in muscle from patients with NIDDM have been reported. In some (17-19) but not all (20-22) studies a reduced GS activity ("total" GS activity) in the presence of a saturating concentration of G6P has been found. Other investigations have shown an impaired GS activity in the presence of physiological concentrations of G6P $(22,23)$ or insulin-resistant in vivo activation of GS (24). Moreover, we recently found an impaired mRNA expression of GS in muscle from NIDDM patients, suggesting defective pretranslational regulation (19). The activity of PFK has been reported to be normal or decreased in muscle tissue from patients with $\operatorname{NIDDM}(25,26)$, whereas mRNA or protein expression of this gene in human muscle has not been investigated.

Recently, cDNAs encoding human skeletal muscle GS (27) and PFK (28) were cloned and sequenced. The polypeptide encoded by the GS gene comprises 737 amino acids, whereas the gene for PFK encodes a protein of 780 amino acids. Based on the predicted amino acid sequences, we have raised polyclonal antipeptide antibodies against both enzymes. Hence, to gain further insight into the abnormal glucose metabolism of skeletal muscle from patients with NIDDM, during basal and insulin stimulated conditions we have examined the interrelationships between in vivo glucose clearance (oxidative and nonoxidative glucose metabolism) and muscle activities as well as immunoreactive protein and mRNA levels of GS and PFK in insulin-resistant NIDDM patients and matched healthy control subjects.

\section{Methods}

Subjects. 19 subjects with NIDDM and 19 normal subjects participated in the study. All were Caucasians and sedentary. The control subjects had normal fasting plasma glucose, normal blood pressure, and no family history of diabetes. Clinical data are presented in Table I. Individuals with NIDDM as defined by the National Diabetes Data Group (29) were recruited from the outpatient clinic at Steno Diabetes Center. Only NIDDM patients with a fasting serum C-peptide level $>0.3 \mathrm{nmol} /$ liter were included in the protocol. 10 patients were on sulfonylurea therapy, 2 were on insulin therapy, and 7 were on weightmaintaining diet therapy alone. The diets typically contained $45 \%$ carbohydrates, $40 \%$ fat, and $15 \%$ protein. No significant differences in clinical data ( Table I) were seen between the group of NIDDM patients treated by diet alone and the group of patients treated with drugs or insulin. The mean \pm SE duration of known diabetes was $4 \pm 1$ yr. None of the participants in the study suffered from liver or kidney disease as evaluated by clinical and standard laboratory examinations, and no subject was taking any other medication known to influence carbohydrate and lipid metabolism. Before participation, the purpose and risks of the study were carefully explained to all of the volunteers and their informed consent was obtained. The protocol was approved by the local Committee of Ethics in Copenhagen and was in accordance with the Helsinki Declaration.

Study protocol. All experiments were started in the fasting state at 8 a.m. after a 10-h overnight fast. A venous blood sample was drawn and concentrations of plasma glucose, serum insulin, serum C-peptide, plasma nonesterified fatty acids (NEFA), and $\mathrm{HbA}_{1 \mathrm{C}}$ were measured. Percutaneous muscle biopsies ( $~ 500 \mathrm{mg}$ ) were obtained under local anesthesia ( $1 \%$ lidocaine without epinephrine) from the vastus lateralis muscle $\sim 20 \mathrm{~cm}$ above the knee, using a modified Bergström needle (Stille-Werner, Copenhagen, Denmark). Muscle samples were blotted to remove blood and connective and adipose tissue, frozen in liquid nitrogen within $30 \mathrm{~s}$, and stored at $-80^{\circ} \mathrm{C}$ until assayed.
Table I. Clinical Data of NIDDM Patients and Control Subjects

\begin{tabular}{lcc}
\hline & NIDDM & Control \\
\hline Sex (F:M) & $6: 13$ & $9: 10$ \\
Age $(\mathrm{yr})$ & $51(40-64)$ & $48(34-65)$ \\
Body mass index $\left(\mathrm{kg} / \mathrm{m}^{2}\right)$ & $27.5 \pm 0.9$ & $27.5 \pm 0.8$ \\
HbA $\mathrm{Ac}_{\mathrm{IC}}(\%)$ & $7.9 \pm 0.5$ & $5.2 \pm 0.1^{*}$ \\
Fasting plasma glucose $(\mathrm{mM})$ & $10.8 \pm 1.1$ & $5.4 \pm 0.1^{*}$ \\
Fasting serum insulin $(\mathrm{pM})$ & $85 \pm 11$ & $55 \pm 5^{\ddagger}$ \\
Fasting serum C-peptide $(\mathrm{nM})$ & $0.78 \pm 0.08$ & $0.63 \pm 0.06$ \\
Fasting plasma NEFA (mM) & $0.73 \pm 0.12$ & $0.52 \pm 0.07$ \\
Steady-state serum insulin & & \\
$\quad$ under clamp (pM) & $1,153 \pm 124$ & $966 \pm 88$ \\
\hline
\end{tabular}

Values are means $\pm \mathrm{SE}$.

${ }^{*} P<0.005 ;{ }^{\ddagger} P<0.05$.

To examine the regulatory effects of insulin in vivo on the enzyme activities of GS and PFK and their specific immunoreactivities and mRNA levels in muscle biopsies, a euglycemic hyperinsulinemic clamp in combination with indirect calorimetry was carried out for $4 \mathrm{~h}$ in nine of the NIDDM patients and seven of the control subjects. At the end of the clamp period a second muscle biopsy was taken at a distance of $5 \mathrm{~cm}$ from the first one.

Euglycemic hyperinsulinemic clamp. Each clamp lasted for $6 \mathrm{~h}$ : a 2-h basal period followed by a 4-h hyperinsulinemic glucose clamp with a muscle biopsy at the end of each study period. Details of the clamp technique have been described previously (30). On the morning of each study an intravenous catheter was inserted into an antecubital vein for infusion of $3-\left[{ }^{3} \mathrm{H}\right]$ glucose, insulin, and glucose. Another catheter was inserted in the contralateral arm for blood sampling, and the arm was placed in a heated box to ensure arterialization of the venous blood. To assess total peripheral glucose uptake, $3-\left[{ }^{3} \mathrm{H}\right]$ glucose was infused throughout the study period. In the control subjects 3$\left[{ }^{3} \mathrm{H}\right]$ glucose was administered as a primed $(25 \mu \mathrm{Ci})$, continuous $(0.25$ $\mu \mathrm{Ci} / \mathrm{min}$ ) infusion, whereas in the NIDDM patients the prime was increased in proportion to the increase in fasting plasma glucose concentration. The continuous infusion of labeled glucose was the same as in the controls $(0.25 \mu \mathrm{Ci} / \mathrm{min})$. The clamp was performed by continuous infusion of $2 \mathrm{mU}$ insulin/ $\mathrm{kg}$ per min (Actrapid; Novo Nordisk, Bagsvaerd, Denmark), and euglycemia was maintained by a variable infusion of $20 \%$ glucose at a rate determined by the measurement of plasma glucose levels at 5-10-min intervals. The steady-state plasma glucose levels during the hyperinsulinemic period were $5.3 \pm 0.1 \mathrm{mM}$ in diabetics and $5.3 \pm 0.1 \mathrm{mM}$ in control subjects.

Glucose disposal. Total glucose disposal rate $\left(R_{\mathrm{d}}\right)$ was calculated from the plasma concentrations of tritiated glucose and plasma glucose using Steele's non-steady-state equations (31). Non-steady-state equations were used since plasma glucose concentrations declined in most diabetic patients during the basal period. In these calculations, the distribution volume of glucose was taken as $200 \mathrm{ml} / \mathrm{kg}$ body weight and the pool fraction as 0.65 . Negative rates of hepatic glucose output (HGO) were calculated in all participants during insulin-stimulated steady-state periods, largely as a consequence of a model error emerging at high rates of glucose metabolism (32). We took the negative numbers to indicate a nil HGO. HGO was fully suppressed during insulin infusion. Thus, glucose infusion rates were used to calculate total glucose disposal rate. Total peripheral glucose uptake was corrected for urinary glucose loss.

Glucose and lipid oxidation. Indirect calorimetry was performed using flow through a canopy gas analyzer system (Deltatrac Metabolic Monitor; Datex, Helsinki, Finland). Briefly, air was suctioned at a rate of 40 liters/min through a canopy placed over the head of the subject. Samples of the inspired and expired air were analyzed for oxygen concentration using a paramagnetic differential oxygen sensor and for carbon dioxide using a infrared carbon dioxide sensor. Signals from the 
gas analyzers were processed by the computer, and oxygen consumption and carbon dioxide production were calculated and recorded once per minute. After an equilibration period of $10 \mathrm{~min}$, the average gas exchange rates recorded over the two 30 -min steady-state periods were used to calculate rates of glucose oxidation and lipid oxidation. Protein oxidation rate was estimated from urea nitrogen excretion ( $1 \mathrm{~g}$ nitrogen $=6.25 \mathrm{~g}$ protein). Rates of oxidation were calculated from Frayn's equation (33). The nonoxidative glucose metabolism was calculated as the difference between $R_{\mathrm{d}}$ and glucose oxidation, as determined by indirect calorimetry.

Determination of GS and PFK activities. Extraction of muscle samples, analysis of protein, and assays for GS were performed as described previously (34). GS activity was assayed in duplicate in the absence or presence of seven concentrations $(0-6.7 \mathrm{mM})$ of G6P. Total activity refers to the GS activity in the presence of a saturating concentration of G6P $(6.7 \mathrm{mM})$. The concentration of UDP- $\left[\mathrm{U}-{ }^{14} \mathrm{C}\right]$ glucose (New England Nuclear, Boston, MA) in the reaction mixture was $0.13 \mathrm{mM}$. GS activity was expressed as nanomoles UDP-glucose incorporated into glycogen per minute per milligram soluble protein in the homogenate. Fractional velocities were calculated as GS activity in the presence of subsaturating levels of G6P divided by GS activity in the presence of 6.7 $\mathrm{mM} \mathrm{G6P.} \mathrm{The} \mathrm{concentration} \mathrm{of} \mathrm{G6P} \mathrm{giving} \mathrm{half-maximal} \mathrm{stimula-}$ tion of GS ( $A_{0.5}$ for GS) was calculated using the Hill plot (35). When different samples $(n=9)$ from the same muscle biopsy were analyzed, the interassay coefficients of variation were 0.12 for $A_{0.5}$ and 0.13 for total GS activity.

PFK activity was assayed spectrophotometrically in duplicate in supernatants of muscle extracts by a modification of the method of Beutler (36). The assay coupled the conversion of F6P to $F 1,6 \mathrm{P}_{2}$ with the oxidation of NADH by means of a series of enzymatic steps including aldolase, triose phosphate isomerase, and $\alpha$-glycerolphosphate dehydrogenase. All three "auxiliary" enzymes were added to the reaction. Activity of PFK was assayed in the presence of $0.1,0.5$, and $2.0 \mathrm{mM}$ F6P. Maximal PFK enzyme activity was calculated using the Michaelis-Menten equation. PFK activity was expressed as nanomoles of F6P converted per minute per milligram of extracted protein. The interassay coefficient of variation was $0.10(n=6)$. To exclude any influence of day-to-day variation in the measurement of enzyme activities, muscle samples from healthy subjects and NIDDM patients were prepared and analyzed pairwise at the same time.

Preparation of GS and PFK antipeptide antibodies. Peptides containing the 9 amino acid GS-carboxy terminus $\left(\left[\mathrm{NH}_{2}\right]\right.$ TSSLGEERN) and the 9 amino acid PFK-carboxy terminus ([ $\left.\mathrm{NH}_{2}\right]-$ KRSGSEAAV) were synthesized (Kem-En-Tec; Copenhagen, Denmark), and were each coupled to BSA using glutaraldehyde. $2 \mathrm{ml} 0.4 \%$ (vol/vol) glutaraldehyde (Sigma G 5882; Sigma Chemical Co., St. Louis, MO) in $0.01 \mathrm{M}$ phosphate buffer, $\mathrm{pH} 7.2$, was added dropwise to a mixture of $3 \mathrm{mg}$ peptide and $28 \mathrm{mg}$ BSA (RIA grade, Sigma A 7888; Sigma Chemical Co.) dissolved in $4 \mathrm{ml} 0.01 \mathrm{M}$ phosphate buffer, $\mathrm{pH}$ 7.2. Stirring was continued for $4 \mathrm{~h}$ at room temperature and overnight at $4^{\circ} \mathrm{C}$, respectively. The product was dialyzed against $0.01 \mathrm{M}$ phosphate and $0.15 \mathrm{M} \mathrm{NaCl}$ buffer, $\mathrm{pH}$ 7.2. Two rabbits were immunized by subcutaneous injections on days $0,14,28,56$, and 84 with $0.1 \mathrm{mg}$ conjugate contained in a volume of $0.5 \mathrm{ml}$ mixed with $0.5 \mathrm{ml}$ adjuvant. The first injection was made with Freund's complete adjuvant and the rest with Freund's incomplete adjuvant. The animals were bled at days 35,63 , and 91 . From each date serum from the two rabbits was pooled. Rabbit immunoglobulin was purified from the serum by precipitation with caprylic acid as described (37).

Immunoblotting. $15-20 \mathrm{mg}$ of frozen muscle $(1 \mathrm{mg}$ tissue $/ 20 \mu \mathrm{l}$ buffer) was homogenized at $4^{\circ} \mathrm{C}$ at $2,000 \mathrm{rpm}$ for $45 \mathrm{~s}$ in a buffer, $\mathrm{pH}$ 7.4 , consisting of $25 \mathrm{mM}$ Hepes, $10 \mathrm{mM} \mathrm{K}$-EDTA, $100 \mathrm{mM} \mathrm{NaF}, 1 \%$ (vol/vol) Triton X-100, $1 \mathrm{mM}$ benzamidine, 900,000 kU/liter Trasylol (aprotinin), and $2 \mathrm{mM}$ PMSF. Connective tissue and insoluble cell constituents without measurable GS or PFK immunoreactivities were removed from homogenate by centrifugation at $6,000 \mathrm{~g}_{\max }(5 \mathrm{~min}$; $4^{\circ} \mathrm{C}$ ). The protein concentration was determined in triplicates on the supernatant by the method of Lowry et al. (38).
Samples, $100 \mu \mathrm{g}$ per lane, were separated in triplicate on a $10 \%$ SDS-PAGE gel with a $4 \%$ stacking gel. A human muscle protein standard preparation was run on each gel in triplicate and used to correct for intergel variations in the immunoblots. Prestained molecular weight markers were from Bio-Rad Laboratories (Richmond, CA). The proteins were electrophoretically transferred to a $0.45-\mu \mathrm{m}$ nitrocellulose membrane ( $200 \mathrm{~V}$ for $2 \mathrm{~h}$ at $0-4^{\circ} \mathrm{C}$; Bio-Rad high efficiency transfer system with plate electrons). After blocking with $5 \%$ (wt/vol) BSA, $20 \mathrm{mM}$ Tris, and $500 \mathrm{mM} \mathrm{NaCl}, \mathrm{pH} \mathrm{7.5,} \mathrm{for} \mathrm{12-24} \mathrm{h} \mathrm{the} \mathrm{mem-}$ branes were incubated with either GS $(1: 250,000)$ or PFK $(1: 25,000)$ antibodies for $12-24 \mathrm{~h}$ at $4^{\circ} \mathrm{C}$. After washing, blots were incubated with ${ }^{35}$ S-protein A (Amersham Corp., Arlington Heights, IL), $0.2 \mu \mathrm{Ci} / \mathrm{ml}$ buffer for $1 \mathrm{~h}$ at $20^{\circ} \mathrm{C}$. Quantitative scanning of autoradiograms was performed within the linear response range, as determined by standard curves of total GS and PFK proteins using a flying spot densitometer (model CS 9000; Shimadzu Corp., Tokyo, Japan). Studies of the immunoreactivity of GS or PFK in muscle specimens from NIDDM patients and controls were run in parallel at the same time. When six different samples from the same muscle biopsy were analyzed, the interassay coefficient of variation was 0.11 for both GS and PFK.

To examine the specificity of the raised antisera, these were tested against purified GS (Sigma G 2259) and fructose-6-phosphate kinase (Sigma F 6877) isolated from rabbit skeletal muscle. Each antiserum gave a clear single band with a molecular mass of 84 and $85 \mathrm{kD}$, respectively, when tested with purified GS and PFK proteins. Absorption of the antisera with the peptides that were used to immunize the rabbits resulted in complete disappearance of the bands at 84 and $85 \mathrm{kD}$, respectively.

RNA extraction and analysis. RNA extraction from muscle biopsies was performed as a modification of the method described by Chomczynski and Sacchi (39). Quantity and purity of RNA were determined by absorbance at 260 and $280 \mathrm{~nm}$. To recognize the size of the transcripts of GS and PFK, to ensure specificity of the cDNA probes, to check for background contamination, and to examine if the transcript sizes were affected by diabetes or insulin infusion, Northern blot analysis was performed. After denaturation, $1.5 \mu \mathrm{g} / \mathrm{lane}$ of total RNA was loaded on $1.2 \%$ ( $\mathrm{vol} / \mathrm{vol}$ ) formaldehyde-agarose gels, blotted, and fixed onto nylon membranes (Gene Screen; Du Pont Co., Wilmington, DE). cDNA probes for human muscle GS (kindly provided by Prof. R. J. Fletterick and Dr. M. F. Browner, University of California, San Francisco, CA), human muscle PFK (kindly provided by Dr. A. McLachlan, Scripps Clinic \& Research Foundation, La Jolla, CA) were labeled with ${ }^{32} \mathrm{P}$ by random priming (GS: Prime-a-Gene ${ }^{\mathrm{TM}}$ labeling kit; Promega Corp., Madison, WI) and nick translation (PFK: Nick Translation System ${ }^{\mathrm{TM}}$; Promega Corp.) and hybridized under stringent conditions (40). The filters were washed with $0.5 \times$ SSC at $55^{\circ} \mathrm{C}$ before autoradiography. To quantitate mRNAs of GS and PFK, the slot blot technique (Bio Dot SF ${ }^{\mathrm{TM}}$; Bio-Rad Laboratories) was used. Before slot blot analysis the integrity of the RNA in each sample was controlled on a $1.0 \%$ agarose gel. Ribosomal bands were visualized by ethidium bromide staining and subsequent ultraviolet illumination. No signs of degradation were found in any of the samples used for slot blot analysis. Total muscle RNA was applied ( $1.5 \mu \mathrm{g} / \mathrm{slot})$ to a nylon membrane and filters were hybridized with cDNA probes for GS and PFK, respectively, as described above. The abundance of GS and PFK mRNA was determined within the linear response range by scanning densitometry (model CS 9000 flying spot densitometer; Shimadzu Corp.). The interassay coefficient of variation for measurement of both GS and PFK mRNA was $0.07(n=6)$.

Other analytical procedures. Glucose in plasma and urine was measured by a hexokinase method (41). Serum insulin and C-peptide concentrations were analyzed by RIA $(42,43)$. $\mathrm{HbA}_{1 \mathrm{C}}$ was measured by isoelectric focusing (44), normal range $4.1-6.1 \%$. Tritiated glucose in plasma was analyzed as described previously (45). NEFA in plasma were determined by the method of Itaya and Michio (46). DNA was measured spectrofluometrically (47).

Statistical analysis. Nonparametric statics were used: the MannWhitney test for unpaired data, the Wilcoxon test for paired data, and 
Spearman's rho for correlation analysis. $P$ values $<0.05$ were considered significant. All data in the text and figures are given as mean $\pm \mathrm{SE}$.

\section{Results}

Glucose and lipid metabolism in vivo. In the basal period of the clamp study, no difference in oxidative and nonoxidative glucose metabolism between the diabetic and control groups was shown $\left(37 \pm 4\right.$ vs. $33 \pm 8 \mathrm{mg} / \mathrm{m}^{2}$ per min and $48 \pm 4$ vs. $44 \pm 7$ $\mathrm{mg} / \mathrm{m}^{2}$ per $\mathrm{min}$ ). Both glucose disposal rate and oxidative and nonoxidative glucose metabolism increased significantly $(P$ $<0.03$ ) from the basal state to the hyperinsulinemic state in diabetic subjects as well as in healthy volunteers. However, after $4 \mathrm{~h}$ of insulin infusion, glucose disposal and nonoxidative glucose metabolism were significantly lower in the diabetic subjects compared with controls ( $325 \pm 31$ vs. $539 \pm 46 \mathrm{mg} / \mathrm{m}^{2}$ per $\mathrm{min}, P<0.01$ and $209 \pm 29$ vs. $403 \pm 39 \mathrm{mg} / \mathrm{m}^{2}$ per $\mathrm{min}, P$ $<0.005$, respectively; Fig. 1). Glucose oxidation rates after insulin stimulation were similar in the two groups. No difference was seen between the diabetic and control subjects in lipid oxidation in the basal period $\left(42 \pm 2 \mathrm{vs.} 48 \pm 5 \mathrm{mg} / \mathrm{m}^{2}\right.$ per min, NS). In both groups lipid oxidation was significantly suppressed after hyperinsulinemia $(P<0.03)$. Again, there was no difference between the two groups ( $17 \pm 4$ vs. $16 \pm 2 \mathrm{mg} / \mathrm{m}^{2}$ per min, NS).

Glycogen synthase activity. Total GS activity (i.e., in the presence of a saturating concentration of the allosteric activator G6P) was $30 \%$ higher in the entire group of control subjects ( $34.9 \pm 2.2$ vs. $24.5 \pm 1.6 \mathrm{nmol} / \mathrm{mg}$ protein per $\min , P<0.005$ ) as compared with the entire group of diabetic patients when measured at the basal serum insulin level (Table II). In the clamped subgroup of diabetics total GS activity was $32 \%$ lower $(P<0.03)$ in the basal state as compared with the matched control group. However, at the highest steady-state serum insulin level no difference was seen between the groups $(28.6 \pm 3.4$

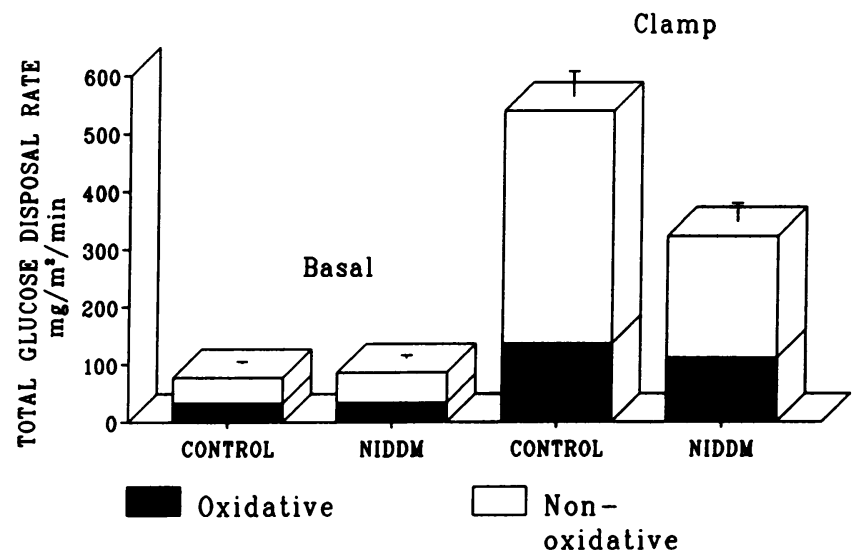

Figure 1. Total glucose disposal rate as well as oxidative and nonoxidative glucose metabolism in seven healthy control subjects and nine patients with NIDDM (subgroups from the entire groups characterized in Table I) during the basal period and after $4 \mathrm{~h}$ of hyperinsulinemia ( $2 \mathrm{mU} / \mathrm{kg}$ per $\mathrm{min}$ ). During the basal period no difference in oxidative and nonoxidative glucose metabolism was seen between the groups. After $4 \mathrm{~h}$ of hyperinsulinemia, glucose disposal rate and nonoxidative glucose metabolism were significantly lower in the NIDDM patients compared with control subjects: $P<0.01$ and $P<0.005$, respectively.
Table II. Basal Activities of GS and PFK in Vastus Lateralis Muscle of NIDDM Patients and Control Subjects

\begin{tabular}{llll}
\hline & $\begin{array}{c}\text { NIDDM } \\
(n=18)\end{array}$ & $\begin{array}{l}\text { Control } \\
(n=17)\end{array}$ & \\
\hline $\begin{array}{l}\text { GS } \\
\text { Total GS activity } \\
\quad \text { (nmol UDPG/mg protein }\end{array}$ & & & \\
$\quad$ per min) & $24.5 \pm 1.6$ & $34.9 \pm 2.2^{*}$ & \\
GS Fv0.1 (\%) & $14.7 \pm 0.9$ & $14.3 \pm 1.2$ & (NS) \\
GS $A_{0.5}$ (mM) & $0.38 \pm 0.02$ & $0.41 \pm 0.03$ & (NS) \\
PFK (nmol F6P/mg protein & & & \\
$\quad$ per min) & & & \\
PFK (F6P 0.1 mM) & $162 \pm 19$ & $195 \pm 22$ & (NS) \\
PFK (F6P 0.5 mM) & $281 \pm 41$ & $329 \pm 42$ & (NS) \\
PFK (F6P 2.0 mM) & $327 \pm 47$ & $376 \pm 47$ & (NS) \\
$V_{\max }$ basal & $347 \pm 53$ & $401 \pm 54$ & (NS) \\
\hline
\end{tabular}

For remaining diabetic and control subjects, an inadequate amount of muscle for enzyme analysis was available. Values are means \pm SE. ${ }^{*} P<0.005$.

$\mathrm{nmol} / \mathrm{mg}$ protein per $\mathrm{min}$ in control subjects vs. $24.2 \pm 1.9$ $\mathrm{nmol} / \mathrm{mg}$ protein per $\min$ in diabetic subjects, $P>0.1$ ). No significant correlations were shown between total GS activity and rate of nonoxidative glucose metabolism either in the basal state or at the end of the clamp period.

Insulin caused an increase in the fractional velocity of GS at the physiological G6P concentration of $0.1 \mathrm{mM}$ in the control group (from $11.6 \pm 1.1$ to $41.1 \pm 5.5 \%, P<0.02$ ), as well as in the diabetic group (from $13.9 \pm 0.9$ to $33.4 \pm 3.4 \%, P<0.02$ ). There was a tendency, although nonsignificant $(P=0.1)$, toward higher insulin responsiveness of GS activation above basal level in the control subjects. No significant correlation was shown between changes in fractional velocity at a G6P concentration of $0.1 \mathrm{mM}$ and changes in nonoxidative glucose metabolism even when data from the two groups of subjects were pooled $(r=0.41, P=0.10)$.

The allosteric activation of GS by G6P showed that $A_{0.5}$ (the G6P concentration that half-maximally stimulates the enzyme) decreased significantly from the basal to the hyperinsulinemic step in the control group (from $0.47 \pm 0.04$ to $0.15 \pm 0.03 \mathrm{mM}, P<0.001$ ), as well as in the diabetic group (from $0.40 \pm 0.04$ to $0.18 \pm 0.04 \mathrm{mM}, P<0.02$ ). No difference was seen in the absolute response between the groups. However, the decrement in $A_{0.5}$ was numerically higher in the control group compared with the diabetic group $(0.32 \pm 0.03$ vs. $0.22 \pm 0.03 \mathrm{mM}, P<0.02)$; i.e., the relative activation of $\mathrm{GS}$ by G6P was $33 \%$ lower in diabetic subjects.

Phosphofructokinase activity. No difference between diabetic and control subjects was seen in the activity of PFK at any concentration of F6P (Table II). The PFK enzyme activities were unaffected by insulin infusion for $4 \mathrm{~h}$ (data not shown). The calculated maximal basal PFK enzyme activity was similar to the activity measured at the high concentration of F6P. Again, no difference was seen between the two groups ( $347 \pm 53$ vs. $401 \pm 54 \mathrm{nmol} / \mathrm{mg}^{-1}$ protein per $\min ^{-1}$ [NS]; diabetics vs. controls, respectively). No significant correlations were found between PFK activity and glucose oxidation rate in the clamped groups either in the basal state or at the end of the clamp period. 
Figure 2. (A) Top, Immunoblotting analysis of
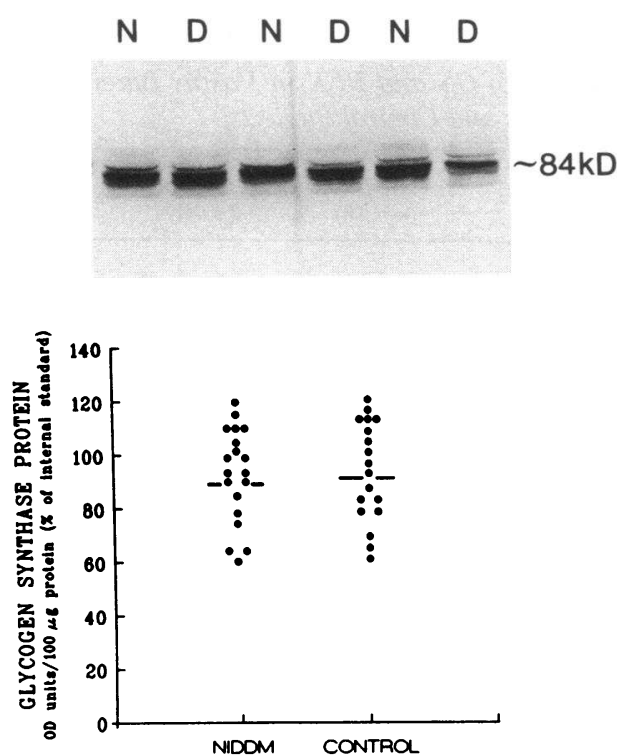
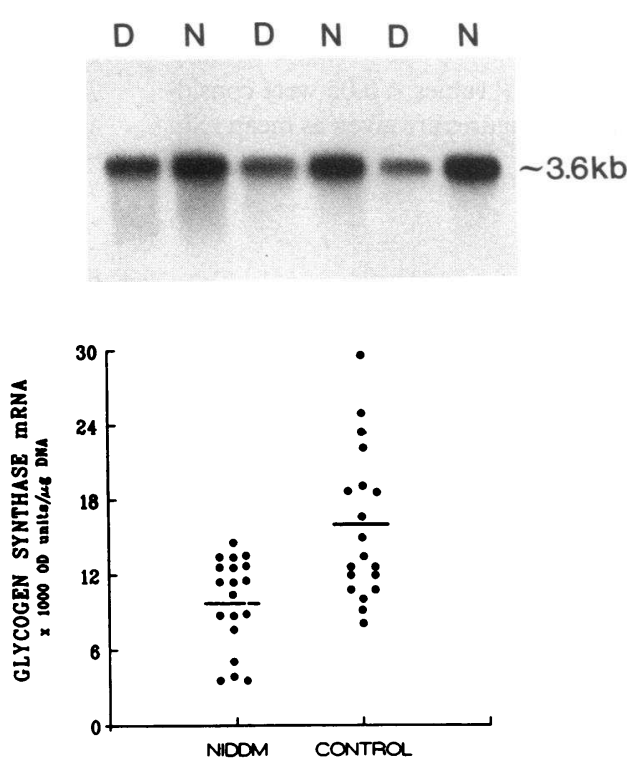
GS protein levels in skeletal muscle (vastus lateralis) in the basal state from healthy control subjects

$(N)$ and NIDDM patients $(D)$. The blot is representative of 37 subjects ( 19 NIDDM patients and 18 control subjects; Table I). Bottom, Results of densitometric scanning of autoradiograms. No differences were seen in GS immunoreactive mass between the groups. $(B)$ Top, Northern blot analysis of GS mRNA levels in skeletal muscle from control subjects $(N)$ and NIDDM patients $(D)$. The blot is representative of 38 subjects ( 19 NIDDM patients and 19 control subjects; Table I). Bottom, Quantitation of slot blots of GS mRNA levels with densitometry showed a 38\% decrease in NIDDM patients $(P<0.005)$.

GS and PFK immunoreactive protein levels. The amount of GS and PFK immunoreactivities in homogenates from human skeletal muscle was quantitated by immunoblotting using antipeptide antisera specific for GS and PFK. In all participants a dominant band of $\sim 84$ and of $85 \mathrm{kD}$, respectively, was identified for GS and PFK immunoreactive proteins (Figs. $2 \mathrm{~A}$ and $3 A$ ).

Densitometric scanning of autoradiograms showed no difference between entire groups in the relative level of GS or PFK protein in the basal state when results were normalized for equal amounts of protein. GS: $92 \pm 4$ ( $n=18$ controls $)$ vs. $89 \pm 5$ OD units $/ 100 \mu \mathrm{g}$ protein (percentage of internal standard) $(n$ $=19$ diabetics, NS; Fig. $2 A$ ); PFK: $94 \pm 4$ ( $n=17$ controls) vs. $98 \pm 5$ OD units/ $100 \mu \mathrm{g}$ protein (percentage of internal stan- dard) ( $n=18$ diabetics, NS; Fig. $3 A$ ). Expressing the GS and PFK immunoreactivities per muscle DNA did not change the interpretation of results since the amounts of DNA recovered were similar in both groups (Table III).

$4 \mathrm{~h}$ of euglycemia and hyperinsulinemia did not give rise to any significant change in the immunoreactive protein level of GS in either of the clamped subgroups. GS: basal state $99 \pm 3$ ( $n$ $=7$ controls) vs. $95 \pm 7$ OD units $/ 100 \mu \mathrm{g}$ protein (percentage of internal standard, $n=9$ diabetics, NS); GS: hyperinsulinemic state $99 \pm 3$ ( $n=7$ controls ) vs. $98 \pm 5$ OD units / $100 \mu$ g protein (percentage of internal standard, $n=9$ diabetics NS; Fig. $4 A$ ). Interestingly, using the $\mathrm{COOH}$-terminal antipeptide antibody against GS, we were able to recognize that more minor bands with apparent molecular masses of $80-82 \mathrm{kD}$ were dissociated
A
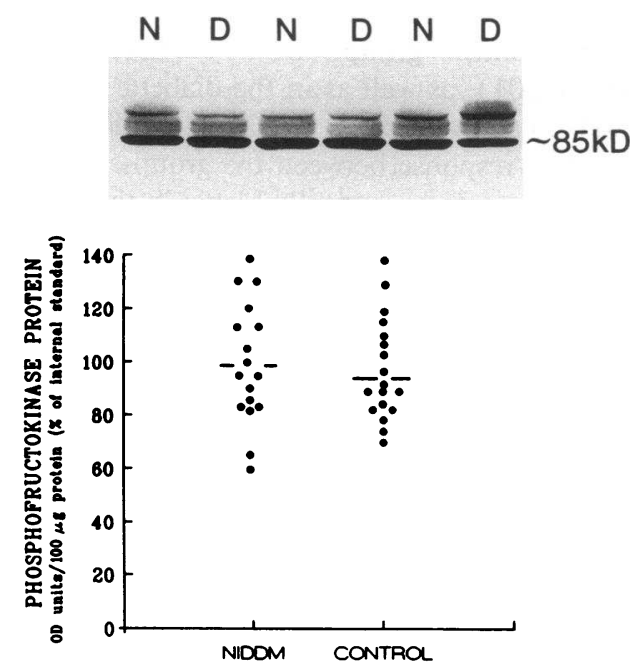

B
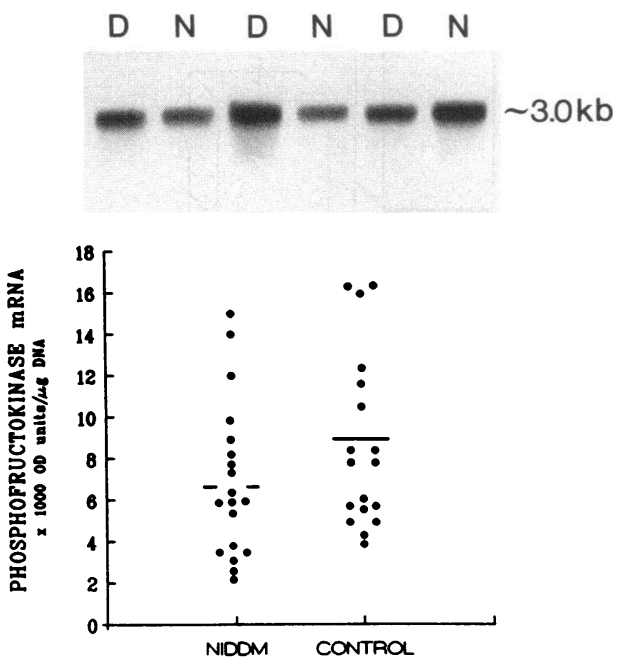

Figure 3. (A) Top, Immunoblotting analysis of PFK protein levels in skeletal muscle (vastus lateralis) in the basal state from healthy control subjects $(N)$ and NIDDM patients $(D)$. The blot is representative of 35 subjects ( 18 NIDDM patients and 17 control subjects; Table I). Bottom, Results of densitometric scanning of autoradiograms. No differences were seen in PFK immunoreactive mass between the groups. (B) Top, Northern blot analysis of PFK mRNA levels in skeletal muscle from control subjects $(N)$ and NIDDM patients (D). The blot is represen-

tative of 38 subjects ( 19 NIDDM patients and 19 control subjects; Table I). Bottom, Quantitation of slot blots of PFK mRNA levels with densitometry showed no differences between the groups. 
Table III. Characteristics of Tissue from Vastus Lateralis Muscle of Study Participants

\begin{tabular}{lrrr}
\hline & $\begin{array}{r}\text { NIDDM } \\
(n=19)\end{array}$ & $\begin{array}{r}\text { Control } \\
(n=19)\end{array}$ & \\
\hline RNA/g tissue $(\mu \mathrm{g} / \mathrm{g})$ & $466 \pm 29$ & $484 \pm 39$ & $(\mathrm{NS})$ \\
DNA/g tissue $(\mu \mathrm{g} / \mathrm{g})$ & $874 \pm 63$ & $803 \pm 42$ & $(\mathrm{NS})$ \\
Protein/g tissue $(\mathrm{mg} / \mathrm{g})$ & $77.2 \pm 2.2$ & $75.1 \pm 1.9$ & (NS) \\
RNA/DNA $(\mu \mathrm{g} / \mu \mathrm{g})$ & $0.6 \pm 0.1$ & $0.6 \pm 0.1$ & (NS) \\
Protein/DNA $(\mathrm{mg} / \mu \mathrm{g})$ & $93.9 \pm 5.5$ & $96.9 \pm 4.5$ & (NS) \\
& & & \\
\hline
\end{tabular}

Values are means \pm SE.

from the dominant band with a $M_{\mathrm{r}}$ of $84 \mathrm{kD}$. The increased electrophoretic migration of GS immunoreactivity may reflect the dephosphorylating effect of insulin on GS. No correlations were found between levels of GS protein and total GS activity either in the basal state $(r=0.12, P=0.51)$ or during hyperinsulinemia $(r=0.14, P=0.60)$.

Similarly, studies in the subgroups showed no regulatory impact of hyperinsulinemia on PFK protein levels (Fig. $4 \mathrm{~B}$ ). No correlations were found between levels of PFK protein and maximal PFK enzyme activity either in the basal state ( $r=0.27, P=0.13$ ) or during hyperinsulinemia $(r=-0.07$, $P=0.80)$.
GS and PFK $m R N A$ levels. In Northern blot analysis the GS cDNA recognized a single transcript of $3.6 \mathrm{~kb}$, the size of which was unaffected by diabetes and insulin infusion (Fig. 2 $B$ ). Loading slot blots with equal amounts of total RNA per slot, the abundance of the specific GS mRNA showed a two- to threefold variation within each group. In the basal state the mRNA level for GS was decreased by $30 \%$ in the total group of NIDDM patients $(23,004 \pm 1,794$ [ $n=19$ diabetics] vs. $31,478 \pm 2,064$ [ $n=19$ controls] OD units $/ 1.5 \mu \mathrm{g}$ total RNA, $P$ $<0.001)$. At the end of the clamp period the level of GS mRNA was still $30 \%$ lower $(P<0.03)$ in the diabetic subject (data not shown). When expressing our data relative to the DNA content of muscle, we found $38 \%$ higher GS mRNA levels in the control group compared with the diabetic group ( $P$ $<0.005)$. No correlations were found between levels of GS mRNA and GS protein either in the basal state $(r=-0.11, P$ $=0.51)$ or after $4 \mathrm{~h}$ of hyperinsulinemia $(r=0.075, P=0.78)$.

Concerning PFK, the cDNA recognized a single transcript of $3.0 \mathrm{~kb}$ in both diabetic and control subjects (Fig. $3 \mathrm{~B}$ ). The abundance of the specific PFK mRNA showed a four- to fivefold variation within each group. No significant difference was seen in the level of mRNA in the basal state $(17,241 \pm 1,768$ [ $n$ $=19$ controls $]$ vs. $14,343 \pm 1,459$ [ $n=19$ diabetics $]$ OD units $/$ $1.5 \mu \mathrm{g}$ total RNA [NS]). $4 \mathrm{~h}$ of euglycemia and hyperinsulinemia did not give rise to any significant change in the level of PFK mRNA in either of the clamped subgroups (data not shown). Again, no difference was seen when PFK mRNA was

A

B
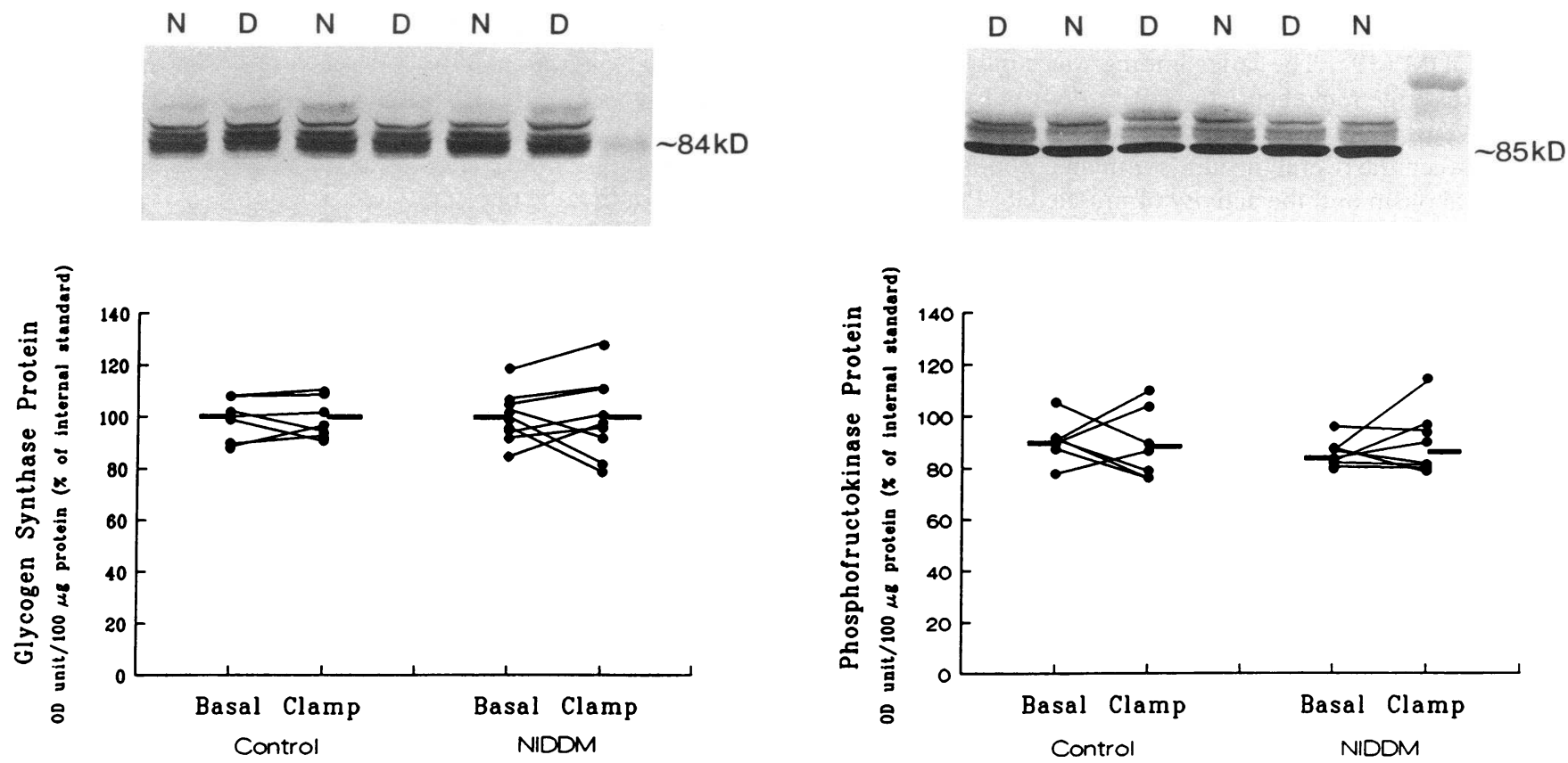

Figure 4. A euglycemic-hyperinsulinemic clamp ( $2 \mathrm{mU} / \mathrm{kg}$ per $\mathrm{min}$ ) was carried out for $4 \mathrm{~h}$ in nine NIDDM patients and seven control subjects (cf. Fig. 1) to examine the regulatory impact of insulin in vivo on muscle GS and PFK protein expressions. $A$ shows the effect of insulin on GS protein as estimated by immunoblotting. Using a $\mathrm{COOH}$-terminal antipeptide antibody against $\mathrm{GS}$, a resolution of the dominant $84-\mathrm{kD}$ band into more minor bands with apparent $M_{\mathrm{r}}$ 's of $80-82 \mathrm{kD}$ was recognized in both groups (top). This finding may reflect the dephosphorylating effect of insulin. Bottom, Densitometric scanning of autoradiograms. Insulin infusion for $4 \mathrm{~h}$ had no regulatory impact on immunoreactive GS mass. $B$ shows the insulin effect on PFK protein as estimated by immunoblotting (top). The lane at the right contains molecular weight markers. Densitometric scanning of autoradiograms demonstrated that insulin infusion for $4 \mathrm{~h}$ had no effect on immunoreactive PFK mass (bottom). No differences were seen between the groups. 
adjusted to the muscle DNA content. No correlations were found between levels of PFK mRNA and PFK protein either in the basal state $(r=-0.25, P=0.15)$ or after $4 \mathrm{~h}$ of hyperinsulinemia $(r=0.41, P=0.12)$.

\section{Discussion}

The major objective of this study was to examine whether quantitatively altered translational products of two rate-limiting key enzymes, GS and PFK, in glucose metabolism of skeletal muscle are involved in the mechanisms behind the impaired insulin-stimulated glucose clearance in patients with NIDDM. We found, however, no evidence for altered immunoreactive mass of GS or PFK in muscle of NIDDM patients with impaired insulin-mediated nonoxidative glucose metabolism.

Glycogen synthase. Under experimental conditions of euglycemia and hyperinsulinemia, nonoxidative glucose metabolism primarily reflects glycogen synthesis with only minor parts of glucose being converted to lipids or lactate $(2,21,24)$. Studies of glucose-tolerant first-degree relative of NIDDM patients have shown significantly reduced insulin-stimulated nonoxidative glucose metabolism (48) and a reduced activation of muscle glycogen synthase (49), suggesting an inherited abnormality of this metabolic pathway. Confirming several previous reports $(17,18,22,23)$, we found that patients with NIDDM were characterized by a $47 \%$ reduction in insulin-stimulated nonoxidative glucose metabolism rate and an $\sim 30 \%$ reduction of total GS activity in muscle tissue in the basal state as well as a $33 \%$ lower relative activation of GS by G6P after in vivo insulin exposure for $4 \mathrm{~h}$. Furthermore, in a recent study we have shown a $39 \%$ reduction in the level of GS mRNA per microgram of DNA of muscle from insulin-resistant patients with NIDDM (19). The latter finding was confirmed in this study. Most (see reference 1 for review) but not all (20) previous investigations have also demonstrated positive correlations between the overall insulin-stimulated nonoxidative glucose metabolism and the activity of muscle GS. Probably due to the low number of subjects who were submitted to insulinglucose clamp in this study, the positive correlation between changes in nonoxidative glucose metabolism and changes in fractional velocity of GS failed to reach statistical significance $(r=0.41, P=0.01)$.

To estimate the relative posttranslational level of GS on the basis of immunoreactivity after blotting we have raised an antipeptide antibody against the $\mathrm{COOH}$ terminus of the human muscle GS. In homogenate of muscle biopsies taken in the basal state the antibody recognized a dominant and specific band with an apparent $M_{\mathrm{r}}$ of $84 \mathrm{kD}$, which corresponds to the cDNA-predicted molecular mass for human muscle GS (83,645 D) (27). However, densitometric scanning of autoradiograms showed no difference in the relative level of immunoreactive GS protein between NIDDM patients and matched control subjects. This disparity between the mRNA and protein expression of the GS gene in NIDDM suggests a difference in turnover rates which might be related to either an increased translatability of GS mRNA or an increased GS protein stability in patients with NIDDM. In favor of increased protein stability is a study in normal man using infusion of labeled amino acids to estimate protein turnover under postabsorptive and hyperinsulinemic conditions (50). It was concluded that acute physiological elevations in circulating insulin levels cause net muscle protein anabolism primarily by inhibiting protein breakdown. In studies of gastrocnemius muscle from rodents (see reference 51 for review), induction of diabetes has been shown to reduce overall protein synthesis rate due to a loss of tissue RNA and reduced translational efficiency (i.e., reduced protein synthesis per unit of RNA). Insulin treatment of these animals restored the efficiency of protein synthesis in muscle to the level of that observed in normal animals without any change in tissue RNA concentration. Hence, in our slightly hyperinsulinemic NIDDM patients normal levels of GS protein despite lower GS mRNA levels might partly be caused by increased protein stability.

Taken together, the available results emphasize the significance of posttranslational abnormalities of GS in muscle of NIDDM patients. One defective posttranslational mechanism found in this study was the reduced allosteric activation by G6P at the end of the hyperinsulinemic clamp period. Insulin (in the absence of G6P) also induces an activation of GS by dephosphorylation processes $(52,53)$. Studies in rabbit skeletal muscle have demonstrated that GS is phosphorylated on nine serine residues in vivo by means of five or more protein kinases. Phosphate release in response to insulin is mainly removed from one tryptic peptide containing three phosphoserine residues, termed $3 \mathrm{a}, 3 \mathrm{~b}$, and $3 \mathrm{c}$, in the highly phosphorylated $\mathrm{COOH}$-terminal end of the enzyme $(8,52)$. Therefore, insulin activates GS either by inhibiting GS kinase-3, (the protein kinase that specifically phosphorylates sites $3 a-c$ [54]) or by stimulating protein phosphatase-1 (the principal enzyme dephosphorylating GS $[55,56])$. Using reverse phase HPLC of complete tryptic digests of purified muscle GS, it has been demonstrated in some $(53,54)$ but not all $(52)$ studies that the phosphate content of sites $3 a-c$ and the neighboring site 2 is selectively elevated in alloxan-induced, hyperinsulinemic diabetic rabbits. These abnormalities are reversible by insulin treatment $(53,54)$. It is known that the degree of phosphorylation of a polypeptide may induce changes in the electrophoretic migration on an SDS-polyacrylamide gel. In fact, it has been shown that the phosphorylation of purified GS from rabbit and rat skeletal muscle $(57,58)$ is correlated with reduced electrophoretic migration from an apparent $M_{\mathrm{r}}$ of $85 \mathrm{kD}$ to 88 or $90 \mathrm{kD}$. However, with our antipeptide antibody against the $\mathrm{COOH}$ terminus of the GS protein, we did not detect any difference in the apparent $M_{\mathrm{r}}$ of GS between well-treated NIDDM patients with mild hyper-insulinemia and control subjects either in the basal state or after $4 \mathrm{~h}$ of in vivo insulin exposure.

Phosphofructokinase. Glycolysis, and especially oxidative glycolysis (glucose oxidation), represents the other major fate of whole body glucose disposal. The flux through this pathway has also been shown to be reduced in NIDDM patients when measured at low physiological plasma insulin levels (1). However, in glucose-tolerant first-degree realtives of NIDDM individuals insulin-mediated glucose oxidation is reported to be normal $(48,49)$. This finding suggests that the impaired glucose oxidation in overt NIDDM may be an acquired abnormality. Furthermore, based on recent data from studies of patients with type VII glycogenosis, an autosomal recessive disorder characterized by a complete lack of the catalytically active muscle type of PFK, it is unlikely that alterations in the PFK protein play any determinant role in the pathogenesis of glucose intolerance or insulin-resistant glucose utilization. Thus, these patients have normal fasting plasma glucose and insulin levels and respond normally to a 75-g oral glucose load (59). In 
addition, despite a total block of muscle tissue glycolysis as documented by muscle accumulation of hexose monophosphates and glycogen and depletion of glycolytic intermediates beyond the metabolic block, a euglycemic, hyperinsulinemic clamp study showed normal whole body glucose disposal rates in these patients (59).

The activity of the key regulatory enzyme of glycolysis in muscle, PFK, has been subject to only a few studies in patients with NIDDM where both decreased (26) or normal (25) PFK activities have been reported. In this investigation we did not demonstrate any difference between diabetics and controls in PFK activities in the basal state or after in vivo insulin exposure.

Human PFK exists as three subtypes, M (muscle), L (liver), and P (platelet), encoded by different genes (see reference 60 for review). All PFKs are polymeric, and muscle PFK is a tetramer. Based on the cDNA sequence, the predicted molecular mass of each M subunit is $85,000 \mathrm{D}$ (28). Recently, it was found that the transcript encoding human muscle PFK undergoes alternative splicing with an alternatively spliced PFK variant lacking the sequence encoded by exon 9 (61). Expression of the alternatively spliced PFK results in the synthesis of a polypeptide lacking 31 amino acids in the amino-terminal half of the subunit. This sequence encodes amino acids predicted to bind the substrate, F6P, and the allosteric modulators, $\mathrm{F} 1,6 \mathrm{P}_{2}$ and $\mathrm{F} 2,6 \mathrm{P}_{2}(61)$. Since our antipeptide $\mathrm{PFK}$ antibody was raised against nine amino acids in exon 24 , it did not allow us to differentiate the relative expression of the alternatively spliced PFK between diabetic and control subjects. However, we did not find any difference between the diabetic and control groups in the total immunoreactive level of human muscle PFK either in the basal period or after $4 \mathrm{~h}$ of hyperinsulinemia. Cloning and sequencing of the PFK cDNA from human skeletal muscle (28) also made it possible to examine the pretranslational regulation of PFK. Northern blot analysis revealed a 3.0-kb transcript, the size of which was unaffected by diabetes and insulin infusion. Quantitation of PFK mRNA by slot blot analysis did not show any significant difference between the groups.

In conclusion, in slightly obese, hyperinsulinemic NIDDM patients with mild hyperglycemia we have found an impaired insulin-mediated nonoxidative glucose disposal rate together with a reduced functional mass of muscle GS; i.e., diminished total activity of GS in the basal state and an impaired insulinstimulated activation of GS in the presence of the allosteric activator G6P. Northern and slot blot analyses revealed a change of the GS gene product with a significantly decreased level of GS mRNA. Using an antipeptide antibody against GS it was shown, however, that the immunoreactive mass of GS was normal in muscle from NIDDM patients, emphasizing that the qualitative posttranslational alterations of GS are likely to be determinant for the reduced glycogen synthesis rate in these subjects. The same NIDDM patients were characterized by normal insulin-stimulated glucose oxidation rates, normal muscle PFK activities, and normal muscle PFK protein and mRNA levels.

\section{Acknowledgments}

The technical assistance of Annemette Forman, Bente Mottlau, Bente Hansen, Helle Fjordvang, and Lisbeth Blak is gratefully acknowledged.

This investigation was supported by grants from the Danish Medical Research Council, the Danish Diabetes Association, the Institute of
Experimental Clinical Research (University of Aarhus, Aarhus, Denmark), and the Bernhard and Marie Kleins Foundation.

\section{References}

1. DeFronzo, R. A., R. Bonadonna, and E. Ferrannini. 1992. Pathogenesis of NIDDM: a balanced overview. Diabetes Care. 15:318-368.

2. Thiebaud, D., R. A. DeFronzo, E. Maeder, E. Jequier, and J. P. Felber. 1982. The effect of graded doses of insulin on total glucose uptake, glucose oxidation, and glucose storage in man. Diabetes. 31:957-963.

3. Rossetti, L., and A. Giaccari. 1990. Relative contribution of glycogen synthesis and glycolysis to insulin-mediated glucose uptake. J. Clin. Invest. 85:17851792.

4. Stalmans, W., M. Bollen, and L. Mvumbi. 1987. Control of glycogen synthesis in health and disease. Diabetes Metab. Rev. 3:127-161.

5. Cohen, P. 1986. Muscle glycogen synthase. In The Enzymes. P. D. Boyer and E. G. Krebs, editors. Harcourt Brace Jovanovich, Publishers, Orlando, San Diego, New York, Austin, Boston, London, Sydney, Tokyo, Toronto. 461-497.

6. Roach, P. J. 1990. Control of glycogen synthase by hierarchal protein phosphorylation. FASEB (Fed. Am. Soc. Exp. Biol.) J. 4:2961-2968.

7. Okubo, M., C. Bogardus, S. Lillioja, and D. M. Mott. 1988. Glucose-6-phosphate stimulation of human muscle glycogen synthase phosphatase. Metab. Clin. Exp. 37:1171-1176.

8. Dent, P., A. Lavoinne, S. Nakielny, F. B. Caudwell, P. Watt, and P. Cohen. 1990. The molecular mechanism by which insulin stimulates glycogen synthesis in mammalian skeletal muscle. Nature (Lond.). 348:302-308.

9. Uyeda, K. 1979. Phosphofructokinase. Adv. Enzymol. Relat. Areas Mol. Biol. 48:193-244.

10. Andréasson, K., D. Galuska, A. Thorne, T. Sonnenfeld, and H. WallbergHenriksson. 1991. Decreased insulin-stimulated 3-O-methylglucose transport in in vitro incubated muscle strips from type II diabetic subjects. Acta Physiol. Scand. 142:255-260.

11. Dohm, G. L., E. B. Tapscott, W. J. Pories, D. J. Dabbs, E. G. Flickinger, D. Meelheim, T. Fushiki, S. M. Atkinson, C. W. Elton, and J. F. Caro. 1988. An in vitro human muscle preparation suitable for metabolic studies. Decreased insulin stimulation of glucose transport in muscle from morbidly obese and diabetic subjects. J. Clin. Invest. 82:486-494.

12. Fink, R. I., P. Wallace, G. Brechtel, and J. M. Olefsky. 1992. Evidence that glucose transport is rate-limiting for in vivo glucose uptake. Metab. Clin. Exp. 41:897-902.

13. Yki-Järvinen, H., K. Sahlin, J. M. Ren, and V. A. Koivisto. 1990. Localization of rate-limiting defect for glucose disposal in skeletal muscle of insulin-resistant type I diabetic patients. Diabetes. 39:157-167.

14. Rothman, D. L., R. G. Shulman, and G. I. Shulman. $1992 .{ }^{31} P$ nuclear magnetic resonance measurements of muscle glucose-6-phosphate. Evidence for reduced insulin-dependent muscle glucose transport or phosphorylation activity in non-insulin-dependent diabetes mellitus. J. Clin. Invest. 89:1069-1075.

15. Mandarino, L. J., A. Consoli, D. E. Kelley, J. P. Reilly, and N. Nurjhan. 1990. Fasting hyperglycemia normalizes oxidative and nonoxidative pathways of insulin-stimulated glucose metabolism in non-insulin-dependent diabetes mellitus. J. Clin. Endocrinol. Metab. 71:1544-1551.

16. Vaag, A., P. Damsbo, O. Hother-Nielsen, and H. Beck-Nielsen. 1992. Hyperglycemia compensates for the defect in insulin-mediated glucose metabolism and in the activation of glycogen synthase in the skeletal muscle of patients with type 2 (non-insulin-dependent) diabetes mellitus. Diabetologia. 35:80-88.

17. Kida, Y., A. Esposito-Del Puente, C. Bogardus, and D. M. Mott. 1990. Insulin resistance is associated with reduced fasting and insulin-stimulated glycogen synthase phosphatase activity in human skeletal muscle. J. Clin. Invest. 85:476-481.

18. Thorburn, A. W., B. Gumbiner, F. Bulacan, G. Brechtel, and R. R. Henry. 1991. Multiple defects in muscle glycogen synthase activity contributes to reduced glycogen synthesis in non-insulin-dependent diabetes mellitus. J. Clin. Invest. 87:489-495.

19. Vestergaard, H., C. Bjørbæk, P. H. Andersen, J. F. Bak, and O. Pedersen. 1991. Impaired expression of glycogen synthase mRNA in skeletal muscle of NIDDM patients. Diabetes. 40:1740-1745.

20. Johnson, A. B., M. Argyraki, J. C. Thow, I. R. Jones, D. Broughton, M. Miller, and R. Taylor. 1991. Impaired activation of skeletal muscle glycogen synthase in non-insulin-dependent diabetes mellitus is unrelated to degree of obesity. Metab. Clin. Exp. 40:252-260.

21. Kelley, D. E., and L. J. Mandarino. 1990. Hyperglycemia normalizes insulin-stimulated skeletal muscle glucose oxidation and storage in noninsulindependent diabetes mellitus. J. Clin Invest. 86:1999-2007.

22. Damsbo, P., A. Vaag, O. Hother-Nielsen, and H. Beck-Nielsen. 1991. Reduced glycogen synthase activity in skeletal muscle from obese patients with and without type 2 (non-insulin-dependent) diabetes mellitus. Diabetologia. 34:239-245.

23. Johnson, A. B., M. Argyraki, J. C. Thow, D. Broughton, I. R. Jones, and R. Taylor. 1990. Effects of intensive dietary treatment on insulin-stimulated skele- 
tal muscle glycogen synthase activation and insulin secretion in newly presenting type 2 diabetic patients. Diabetic Medicine. 7:420-428.

24. Shulman, G. I., D. L. Rothman, T. Jue, P. Stein, R. A. DeFronzo, and R. G. Shulman. 1990. Quantitation of muscle glycogen synthesis in normal subjects and subjects with non-insulin-dependent diabetes by ${ }^{13} \mathrm{C}$ nuclear magnetic resonance spectroscopy. $N$. Engl. J. Med. 322:223-228.

25. Mandarino, L. J., K. S. Wright, L. S. Vertity, J. Nichols, J. M. Bell, O. G. Kolterman, and H. Beck-Nielsen. 1987. Effects of insulin infusion on human skeletal muscle pyruvate dehydrogenase, phosphofructokinase and glycogen synthase. J. Clin. Invest. 80:655-663.

26. Falholt, K., I. Jensen, S. Lindkær Jensen, H. B. Mortensen, A. Vølund, L. G. Heding, P. Nørskov Petersen, and W. Falholt. 1988. Carbohydrate and lipid metabolism of skeletal muscle in type 2 diabetic patients. Diabetic Medicine. 5:27-31.

27. Browner, M. F., K. Nakano, A. G. Bang, and R. J. Fletterick. 1989. Human muscle glycogen synthase cDNA sequence: a negatively charged protein with an asymmetric charge distribution. Proc. Natl. Acad. Sci. USA. 86:14431447.

28. Sharma, P. M., G. R. Reddy, S. Vora, B. M. Babior, and A. McLachlan. 1989. Cloning and expression of a human muscle phosphofructokinase cDNA. Gene (Amst.). 77:177-183.

29. National Diabetes Data Group. 1979. Classification and diagnosis of diabetes mellitus and other categories of glucose intolerance. Diabetes. 28:10391057.

30. DeFronzo, R. A., J. D. Tobin, and R. Andres. 1979. Glucose clamp technique: a method for quantifying insulin secretion and resistance. $\mathrm{Am}$. J. Physiol. (Endocrinol. Metab.) 6:E214-E223.

31. Steele, R. 1959. Influence of glucose loading and of injected insulin on hepatic glucose output. Ann. NY Acad. Sci. 82:420-430.

32. Cobelli, C., A. Mari, and E. Ferrannini. 1987. Non-steady state: error analysis of Steele's model and development for glucose kinetics. Am. J. Physiol. 252:E679-E689.

33. Frayn, K. N. 1983. Calculation of substrate oxidation rates in vivo from gaseous exchange. J. Appl. Physiol. 55:628-634.

34. Bak, J. F., and O. Pedersen. 1990. Exercise-enhanced activation of glycogen synthase in human skeletal muscle. Am. J. Physiol. (Endocrinol. Metab.) 258:E957-E963.

35. Kochan, R. G., D. R. Lamb, S. A. Lutz, C. V. Perrill, E. M. Reinman, and K. K. Schlender. 1979. Glycogen synthase activation in human skeletal muscle: effects of diet and exercise. Am. J. Physiol. (Endocrinol. Metab.) 236:E660-E666.

36. Beutler, E. 1971. Phosphofructokinase. In Red Cell Metabolism: A Manual of Biochemical Methods. E. Beutler, editor. Grune \& Stratton, Inc., New York. 42-44.

37. McKinney, M., and A. Parkinson. 1987. A simple, non-chromatographic procedure to purify immunoglobulins from serum and ascites fluid. J. Immunol. Methods. 96:271-278.

38. Lowry, O. H., N. J. Rosebrough, A. L. Farr, and R. J. Randall. 1951. Protein measurements with the Folin phenol reagent. J. Biol. Chem. 193:265275.

39. Chomczynski, P., and N. Sacchi. 1986. Single-step method of RNA isolation by acid guanidinium thiocyanate-phenol-chloroform extraction. Anal. Biochem. 162:156-159.

40. Pedersen, O., J. F. Bak, P. H. Andersen, S. Lund, D. E. Moller, J. S. Flier and B. B. Kahn. 1990. Evidence against altered expression of GLUT1 or GLUT4 in skeletal muscle of patients with obesity or NIDDM. Diabetes. 39:865-870.

41. Andersen, I., and S. Hannibal. 1983. Analytical and economical optimization of a glucose method with immobilized enzymes. J. Autom. Chem. 5:188192.
42. Heding, L. G. 1972. Determination of total serum insulin (IRI) in insulintreated diabetic patients. Diabetologia. 8:260-266.

43. Heding, L. G. 1975. Radioimmunological determination of human Cpeptide in serum. Diabetologia. 11:541-548.

44. Mortensen, H. B. 1980. Quantitative determination of hemoglobin $A_{1} c$ by thin layer isoelectric focusing. J. Chromatogr. 182:325-333.

45. Hother-Nielsen, O., O. Schmitz, J. F. Bak, and H. Beck-Nielsen. 1987. Enhanced hepatic insulin sensitivity, but peripheral insulin resistance in patients with type I (insulin-dependent) diabetes. Diabetologia. 30:834-840.

46. Itaya, K., and U. Michio. 1965. Colorimetric determination of free fatty acids in biological fluids. J. Lipid Res. 6:16-20.

47. Labarca, C., and K. Paigen. 1980. A simple, rapid and sensitive DNA assay procedure. Ann. Biochem. Exp. Med. (Calcutta). 102:344-351.

48. Eriksson, J., A. Franssila-Kullunki, A. Ekstarnd, C. Salorante, E. Widén, C. Schalin, and L. Groop. 1989. Early metabolic defects in persons at increased risk for non-insulin-dependent diabetes mellitus. N. Engl. J. Med. 321:337-343.

49. Schalin-Jäntti, C., M. Härkönen, and L. Groop. 1992. Impaired activation of glycogen synthase in people at increased risk for developing NIDDM. Diabetes. 41:598-604.

50. Gelfand, R. A., and E. J. Barrett. 1987. Effect of physiologic hyperinsulinemia on skeletal muscle protein synthesis and breakdown in man. J. Clin. Invest. 80:1-6.

51. Jefferson, L. S. 1980. Role of insulin in the regulation of protein synthesis (Lilly Lecture 1979). Diabetes. 29:487-496

52. Parker, P. J., F. B. Caudwell, and P. Cohen. 1983. Glycogen synthase from rabbit skeletal muscle: effect of insulin on the state of phosphorylation on the seven phosphoserine residues in vivo. Eur. J. Biochem. 130:227-234.

53. Sheorain, V. S., H. Juhl, M. Bass, and T. R. Soderling. 1984. Effects of epinephrine, diabetes, and insulin on rabbit skeletal muscle glycogen synthase. $J$ Biol. Chem. 259:7024-7030.

54. Sheorain, V. S., S. Ramakrishna, W. B. Benjamin, and T. R. Soderling 1985. Phosphorylation of sites 3 and 2 in rabbit skeletal muscle glycogen synthase by multifunctional protein kinase (ATP-citrate lyase kinase). J. Biol. Chem 260:12287-12292.

55. Strålfors, P., A. Hiraga, and P. Cohen. 1985. The protein phosphatases involved in cellular regulation. Purification and characterisation of the glycogenbound form of protein phosphatase-1 from rabbit skeletal muscle. Eur. J. Bio chem. 149:295-303.

56. Ingebritsen, T. S., A. A. Stewart, and P. Cohen. 1983. The protein phosphatases involved in cellular regulation. Measurement of type- 1 and type-2 protein phosphatases in extracts of mammalian tissues: an assessment of their physiological roles. Eur. J. Biochem. 132:297-307.

57. DePaoli-Roach, A. A., Z. Ahmad, M. Camici, J. C. Lawrence, and P. J. Roach. 1983. Multiple phosphorylation of rabbit skeletal muscle glycogen synthase. J. Biol. Chem. 258:10702-10709.

58. Kaslow, H. R., and D. D. Lesikar. 1984. Isoenzymes of glycogen synthase. FEBS (Fed. Eur. Biochem. Soc.) Lett. 172:294-298.

59. Katz, A., M. K. Spencer, S. Lillioja, Z. Yan, D. M. Mott, R. G. Haller, and S. G. Lewis. 1991. Basal and insulin-mediated carbohydrate metabolism in human muscle deficient in phosphofructokinase 1. Am. J. Physiol. (Endocrinol Metab.) 261:E473-E478.

60. Vora, S. 1983. Isozymes of human phosphofructokinase: biochemical and genetic aspects. Curr. Top. Biol. Med. Res. 11:3-23.

61. Sharma, P. M., G. R. Reddy, B. M. Babior, and A. McLachlan. 1990. Alternative splicing of the transcript encoding the human muscle isoenzyme of phosphofructokinase. J. Biol. Chem. 265:9006-9010. 